\title{
THE PROSPECT OF AGROINDUSTRY DEVELOPMENT IN KAKAO UNGGUL COOPERATION IN TANAH LUAS SUB DISTRICT, NORTH ACEH DISTRICT OF INDONESIA
}

\author{
Barmawi ${ }^{*}$, Indra, Hakim L. \\ Faculty of Agriculture, University of Syiah Kuala, Indonesia \\ *E-mail: awinazal1985@gmail.com
}

\begin{abstract}
This study aims to analyze the level of profit, the level of business feasibility in terms of the availability of raw materials, marketing aspects and analysis of financial aspects. The research effort is expected to solve problems in the development of cocoa processing industry in the Kakao Unggul Cooperation business in North Aceh District. This research was conducted using a descriptive approach and quantitative analysis. Descriptively, this study describes the availability of raw materials, market prospects and marketing strategies while quantitative analysis calculated costs, production, selling prices, income and profits and business feasibility analysis of the financial aspects of the business. The results showed that the Kakao Unggul Cooperation Agro industry has a prospect to be developed, this is indicated by the availability of sufficient raw materials needed, from the marketing aspect the cocoa processed products is have a chance to be developed, this can be seen from the increasing number of demand while the capacity and production capacity temporarily increases still limited. The results of the analysis of the financial aspects of the cocoa processing agro industry business in North Aceh District are feasible to develop in terms of the Net Present Value is $141,364,032$, the Net benefit cost of ratio obtained at 1.64, Internal rate of return (IRR) is $35.69 \%$ and point return home (break event) occurs 4 years 2 months 17 days.
\end{abstract}

\section{KEY WORDS}

Cocoa, agro-industry, analysis, financial aspects, non-financial aspects.

Cacao has become familiar for Acehnese people as it one of the leading commodities there. The cacao qualities in the other side make it possible to export to the other countries which can be advantages for Aceh province. The area of cacao plantation in Aceh can be found in Pidie, Pidie Jaya, Bireun, North Aceh, East Aceh and also in south east Aceh districts. As one of the cocoa producing areas, North Aceh is in fourth place after Pidie, Pidie Jaya and Bireun Districts.In further, Tanah Luas Sub-District is one of the cocoa producing areas in North Aceh District, with an area of \pm 100.00 hectares, in 2015 with a total production of 74 tons. Viewed from the area compared to other areas in North Aceh District, Tanah Luas Sub-District still has the potential for future cocoa development as it supported by the wide area available and on the other side supported by the post-harvest management activities which is implemented by establishing the cocoa processing agro-industry business in 2015 .

It is hoped that the cocoa processing industry managed by the "Kakao Unggul" Cooperation will be able to accommodate cocoa production in North Aceh and change the habits and dependence of cocoa farmers to sell cocoa products directly to collectors to be sent to other regions, especially to North Sumatra. This will result in the low income of farmers because of the length of the marketing chain that occurs and the absence of margins obtained because farmers only sell cocoa in the form of seeds.

The processing industry of Cocoa is assisted by the Non-Governmental Organization Bumoe Malikussaleh namely "Kakao Unggul" Cooperation which has been running for \pm 2 years, but the presence of the Cocoa processing industry does not have a major influence on cocoa development and economic growth in North Aceh District, this is because the processing industry managed by the Cooperation has not been able to operate optimally to accommodate and process cocoa production in the District. 
It is expected that the Cocoa processing Agroindustry in Tanah Luas Subdistrict would be able to make the production of cocoa produced by farmers as a product. In fuhter the products would add value and create high economic value to increase income or gain profits. The Processed Agroindustry Advantages Cocoa is the difference between the amount of the amount of receipts and the amount of production costs incurred. The amount of profit received can be used as a benchmark in looking at the development of cocoa processed agroindustry in the long term (Aisyah and Friends, 2014). Furthermore, small-scale Cacao processing industries can contribute to expanding employment. With the ultimate goal of being able to provide an impact and contribution from Cacao processed agroindustry directly or indirectly to the national economy (Sutanto, 2002).

With the research on business feasibility and people's cocoa development strategy, the problem of developing the cocoa processing industry in the management model and decision making for the development of cocoa agroindustry has become clearer and directed at the "Kakao Unggul" Cooperation business in North Aceh District.

\section{METHODS OF RESEARCH}

To analyze the prospect of developing Cocoa Agro industry in North Aceh District, the writer uses descriptive and analytical approaches. Descriptively this study describes the availability of raw materials for cocoa processing, then also describes the market prospects and marketing strategies that occur in the product distribution process from cocoa processing to end consumers, while in analysis is calculating all components of costs incurred, production, selling prices and calculating the income and profits of the cocoa processing business and the business feasibility analysis of the financial aspects with the following approaches:

Analysis of revenue and profit. The revenue is the proceeds from the sale of processed cocoa beans received by the entrepreneur or business owner before deducting the costs incurred, it is calculated by equality:

$$
\mathrm{TR}_{\mathrm{n}}=\mathrm{P}_{\mathrm{n}} \times \mathrm{Q}_{\mathrm{n}} \text { (Dumairy, 1986) }
$$

Next to calculate profits, according to Dumairy (1986) can be done using the following equation:

$$
\pi=\mathrm{TR}-\mathrm{TC}
$$

Business Financial Analysis. Yacob (2007) states to analyze feasible or inappropriate business together with four meanings of general investment.

Analysis of Net Present Value (NPV), using equations:

$$
N P V=\sum \frac{B t-C t}{(1+i)^{t}}
$$

Analysis of Net Benefit Cost Ratio (Net B / C), the equation:

$$
N e t B \quad / C=\frac{\sum_{i=1}^{n} N B i(+)}{\sum_{i=1}^{n} N B_{i}(-)}
$$

Internal Rate of Return (IRR) analysis, the equation is

$$
\left[\frac{N P V_{1}}{N P V_{1}-N P V_{2}}\right]\left(i_{2}-i_{1}\right)
$$




$$
\operatorname{IRR}=\left(\mathrm{i}_{1}\right)+
$$

Break-even point analysis, the general equation used is

$$
B E P=T p-1+\frac{\sum_{i=1}^{n} T c i-\sum_{i=1}^{n} B_{i e p-1}}{B P}
$$

\section{RESULTS AND DISCUSSION}

The realization of the Company's concern and concern for the business environment as an effort to increase farmers' income, in 2015 the Pertamina Hulu Energi NSB company realized great care and attention by building and inaugurating Cooperation buildings, warehouses, and cocoa bean processing machines in Tanah Luas Sub District precisely in Gampong Rayeuk Munye. The assistance was given to farmer groups in the region by establishing a Cooperation called "Kakao Unggul". The activities carried out by the Cooperation are expected to be able to process cocoa beans produced by farmers in the region into high-quality processed products with the application of good post-harvest handling technology to be then marketed to a number of food processing industries using raw materials from cocoa processed products.

Cocoa commodity-based Cooperation is one form of efforts to improve the welfare of cocoa farmers designed to increase the income of cocoa farmers, especially cocoa farmers in the area assisted by Exxon Mobil Oil Indonesia (EMOI). The establishment of a cocoa farmer Cooperation is expected to have 3 comprehensive business units, including: agricultural service business units fermented cocoa processing and marketing business units, and cocoa waste processing business units and those are aimed to create sustainable cocoa production and sustainable community welfare.

The program was carried out simultaneously and synergistically between the NGO Siaga Bumoe Malikussaleh (BM), the Agro Bina Mandiri Foundation (YABM) and the Penabulu Foundation. In this program Penabulu strengthened the financial and accounting aspects of Cooperations, and encouraged the establishment of a Cocoa Processing and Marketing Business Unit as a form of Cooperation business unit.The construction of the office and warehouse of the plantation Cooperation "Kakao Unggul" is located in Rayek Meunye Village, Tanah Luas Sub District, North Aceh with own construction began in August 2015.The groundbreaking was carried out on 11 August 2015, with the support of SKK Migas. The event was held by 3 (three) Institutions namely:

- NGO Siaga Bumoe Malikussaleh Residents;

- Penabulu Foundation;

- Agro Bina Mandiri Foundation.

Potential development of the plantation sector and the trade in cocoa commodity in North Aceh District has a great opportunity, this is seen from the increasing economic activities that can increase people's income, one of which is the establishment of a plantation Cooperation institution that holds and processes farmers' produce into valuable processed products economical. The fact that has happened so far, farmers in the North Aceh area tend to sell cocoa commodities in the form of seeds, so that the income received by farmers is smaller.

By the guidance and empowerment of farmers, they are expected to be able to process cocoa beans into processed products in the form of pasta or chocolate flour whose selling value is higher than just selling cocoa beans.

If the cocoa potential is developed with a system of empowerment and assistance for small businesses engaged in processing cocoa beans into chocolate flour, the economic growth in the area will grow and increase. Furthermore, it is expected that greater attention from relevant agencies in seeing the potential of cocoa in a focused and directed manner, and finding solutions on how to not produce cocoa bean production in North Aceh Regency 
and surrounding areas, but marketed in the form of processed cocoa such as flour, pasta and other preparations to obtain greater added value.

The cocoa processing industry in Tanah Luas sub-district is a business unit managed and run by the "Kakao Unggul " Cooperation management to process raw materials in the form of cocoa beans obtained from members of Cooperations totaling 80 people spread over two (2) sub-districts namely Tanah Luas and Matang Kuli. The raw materials are then accommodated and post-harvest handling processes are carried out through drying, heating / oven activities to reduce water content. The Cocoa beans are raw materials that are processed to produce various processed cocoa which will then be reused as raw materials for other industries both small scale and large scale industries. The raw material is an important element in the production process and guarantees continuous production. The availability of raw materials for cocoa processing in the agro-industry is highly dependent on the participation and active participation of Cooperation members to sell cocoa products to the Cooperation management, so that each member is required to sell cocoa products to the Cooperation with varying selling prices following the prevailing prices in the market, so that Cooperation members do not feel disadvantaged. In order to meet the raw material needs that are sometimes insufficient from the members of the Cooperation, the entrepreneurs took the initiative to establish partnerships with collector traders in the area of the business to sell cocoa beans to Cooperations to ensure availability of raw materials for the cocoa processing process.

Calculation of the total cost of purchasing raw materials is all costs incurred for the purchase of cocoa beans from cocoa farmers around the place of business, the amount incurred depends on the amount of dry cocoa purchased by the entrepreneur / Cooperation management for processing, in one month the production process requires $\pm 300 \mathrm{~kg}$ of dried cocoa beans. While the total cost of purchasing supporting raw materials is the cost incurred by the management of the Cooperation to purchase materials / materials that support the production process. The cost of supporting cocoa processing is used to buy sugar, milk and packaging. The detail of the ingredients used in the cocoa processing business in the "Kakao Unggul" in Tanah Luas Sub District can be seen in the following table:

Table 1 - The use of Raw Materials for Cacao Processing in the "Kakao Unggul" Cooperation in Tanah Luas Sub District

\begin{tabular}{|c|c|c|c|c|c|}
\hline No. & Description & Unit & Price (Rp) & Volume & Amount (Rp) \\
\hline 1. & $\begin{array}{l}\text { Main Raw Materials } \\
\text { (Dried Cocoa Beans) }\end{array}$ & $\mathrm{Kg}$ & 35.000 & 300 & 10.500 .000 \\
\hline 2. & $\begin{array}{l}\text { Supporting Materials } \\
\text { - Milk } \\
\text { - Sugar } \\
\text { - Packaging } \\
\end{array}$ & $\begin{array}{l}\text { Liter } \\
\mathrm{Kg} \\
\mathrm{Kg} \\
\end{array}$ & $\begin{array}{l}20.000 \\
13.000 \\
45.000\end{array}$ & $\begin{array}{l}2 \\
2 \\
1 \\
\end{array}$ & $\begin{array}{l}40.000 \\
26.000 \\
45.000 \\
\end{array}$ \\
\hline & Total & & & & 10.611 .000 \\
\hline
\end{tabular}

Source: Data processed.

Based on the table above, it can be explained that the cocoa processing business in the "Kakao Unggul" Cooperation in Tanah Luas Sub district incurred the cost of purchasing inputs in the form of dried cocoa beans and supporting inputs within one (1) month production process of Rp. 10,611,000 and costs the most widely spent is to buy the main raw material in the form of dried cocoa beans in the amount of Rp. 10,500,000.

From the raw materials of agroindustry that uses cocoa which is operated by a "Superior Cocoa" Cooperation, it is feasible to be developed, this is due to the operational ability to get better results. Based on the analysis carried out, the availability of raw materials for cocoa is far greater than the raw material requirements of cocoa beans for the processing industry, this is due to a good collaboration between members and management of Cooperations in the process of buying and harvesting crops from farmers and Cooperations around the location of the cocoa processing Cooperation. 
Marketing is the process of distributing products both physically and economically from producers through the role of other marketing actors such as intermediary traders to end consumers. In the marketing process, producers must consider the marketing channels that will be used to distribute their products to consumers (Praza, 2017). Marketing activities of processed cocoa products in the form of pasta and cocoa powder are carried out by directly offering other entrepreneurs both home industries and retailers in the market in Tanah Luas Sub District and other market areas in North Aceh District and Lhokseumawe. The demand for processed flour and pasta from Cocoa continues to increase, although not too large. To be clearer, the description of the demand for processed cocoa products in North Aceh District can be seen in the following figure:

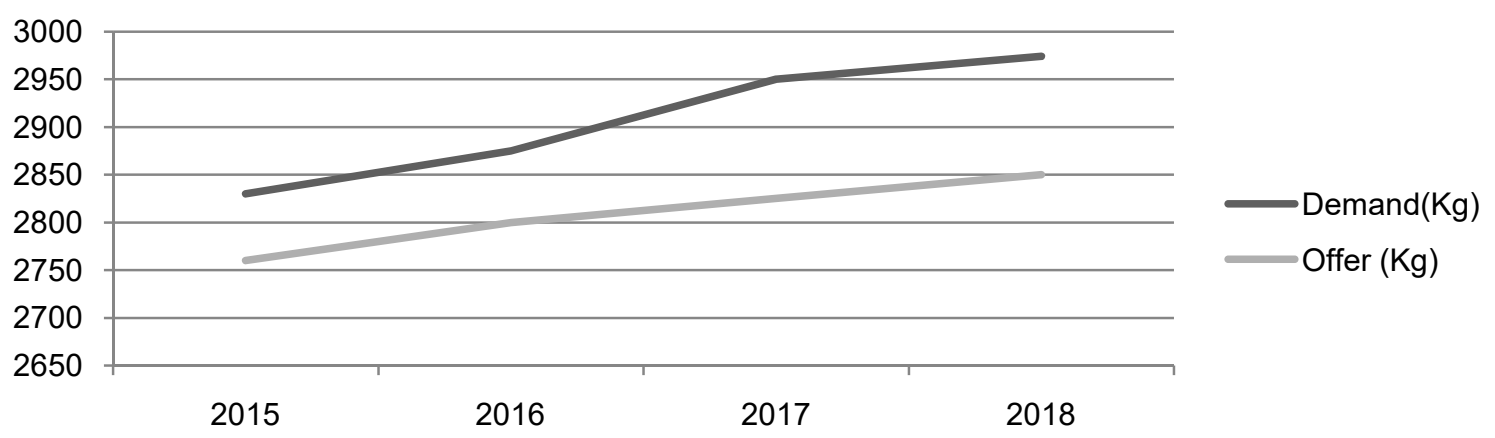

Figure 1 - Demand for processed cocoa products in North Aceh District

(Source: Primer Data, Processed 2018)

Demand for processed Cocoa products continues to increase while the amount offered is still lacking or little, this is due to the growing development of partner businesses that collaborate with cocoa processing agro industry businesses, especially in terms of providing raw materials for the business, so that there will be greater opportunities for development Cocoa processing agro industry business in the future, especially in increasing production capacity.

In addition, in marketing processed products produced by "superior cocoa" Cooperations, Cooperation managers establish Cooperation relations with other cocoa processing industries in Pidie Jaya District, namely UD. Socolatte, which has already run a cocoa processing business with various types of processed products. Cooperations operating in North Aceh District act as suppliers of raw materials for the Cocoa processing industry, resulting in cocoa derivative products that can be directly consumed by consumers.

The marketing activities carried out have been going on since the first time this business was run with a strong commitment to complement and need each other, especially in the aspects of product marketing and distribution, so that the owners and managers of UD. Socolatte will be willing to accommodate all products produced by the "Kakao Unggul" Cooperation so that in the marketing aspects of cocoa flour and fat produced by the agro industry it is very convincing and very likely to be improved.

Every effort in the production process definitely requires equipment in order to support the smooth running of the business. In the use of equipment, the Agro processing business does not have problems because this equipment can be easily obtained. The details of the investment costs in the Cocoa Processing Agro industry in Tanah Luas Sub District in North Aceh District are presented in the table 2.

Based on the data provided in the table, it can be calculated that the total cost of equipment spent on the Cocoa Processing Cooperation in Tanah Luas Sub District, North Aceh District is Rp. 56,750,000. The biggest cost is for building registration, which is $\mathrm{Rp}$. $45,000,000$, and the reverse fee is to buy cleaning equipment in the form of brooms, which is Rp. 70,000. Depreciation value of equipment is Rp. 4,460,625 / year or Rp. 371,718.75 in one production process. 
Table 2 - Details of Investment in Superior Cocoa Agro industry in Tanah Luas Sub District in North Aceh District, Year 2018

\begin{tabular}{|c|c|c|c|c|c|c|}
\hline No & Equipment & Total & $\begin{array}{c}\text { Price } \\
(\text { Rp/Unit })\end{array}$ & The amount of Cost (Rp) & Economic Age & Depreciation \\
\hline 1 & Factory building & 1 & 45.000 .000 & 45.000 .000 & 25 & 1.800 .000 \\
\hline 2 & Powder grinding machine & 1 & 1.850 .000 & 1.850 .000 & 15 & 123.333 \\
\hline 3 & Plastic adhesive machine & 2 & 700.000 & 1.400 .000 & 12 & 116.667 \\
\hline 4 & Refrigerator & 2 & 2.000 .000 & 4.000 .000 & 5 & 800.000 \\
\hline 5 & Gas stove & 2 & 350.000 & 700.000 & 5 & 140.000 \\
\hline 6 & Pan & 3 & 55.000 & 165.000 & 2 & 82.500 \\
\hline 7 & Basin & 10 & 40.000 & 400.000 & 1 & 400.000 \\
\hline 8 & Digital scales & 2 & 350.000 & 700.000 & 5 & 140.000 \\
\hline 9 & Chocolate mold & 3 & 395.000 & 1.185 .000 & 8 & 148.125 \\
\hline 10 & Scissor & 5 & 20.000 & 100.000 & 2 & 50.000 \\
\hline 11 & Tent & 5 & 200.000 & 1.000 .000 & 2 & 500.000 \\
\hline 12 & Shovel & 4 & 45.000 & 180.000 & 2 & 90.000 \\
\hline 13 & Broom & 2 & 35.000 & 70.000 & 1 & 70.000 \\
\hline \multicolumn{2}{|c|}{ Total } & 56.750 .000 & - & 4.460 .625 \\
\hline
\end{tabular}

Source: Primer Data (Processed 2018).

The value of production is the size of the value of the production obtained by the cocoa processing businessman from the results of processing cocoa into processed products which is strongly influenced by the size of the production and the level of production prices. For more details, the condition of the average production value in the cocoa processing agro industry business in Tanah Luas Sub-District North Aceh District can be seen as the table below:

Table 3 - Production, Selling price and Production Value

\begin{tabular}{llll}
\hline No. & Description & Unit & $\begin{array}{l}\text { Price/Amount } \\
\text { (Rp) }\end{array}$ \\
\hline 1 & Production of cocoa paste / powder & $\mathrm{Kg}$ & 125 \\
2. & Cocoa fat production & $\mathrm{Kg}$ & 104 \\
3. & Price & & \\
& a. cocoa paste / powder & $\mathrm{Rp} / \mathrm{kg}$ & 120.000 \\
& b. Cocoa fat & $\mathrm{Rp} / \mathrm{kg}$ & 110.000 \\
$4 . \quad$ & $\mathrm{Rp}$ & 15.000 .000 \\
& Value of Production Results & $\mathrm{Rp}$ & 11.400 .000 \\
& a. cocoa paste / powder & $\mathrm{Rp}$ & 26.440 .000 \\
\hline
\end{tabular}

Source: Primer Data (processed 2018).

The table illustrates that the production of processed cocoa produced by the cocoa processing agro industry in Tanah Luas Sub District North Aceh District per month is $125 \mathrm{~kg}$ of cocoa paste and $104 \mathrm{~kg}$ of cocoa fat, with a selling price of Rp. 120,000 per kilogram and Rp. 110,000 per kilogram, the total value of production is obtained, which is Rp. $26,440,000$ in one month of the production process.

A business that is run can be categorized as a business that has a high level of development, if the fixed costs (fix costs) issued are greater than the cost of variables (variable costs). The calculation of production costs is very important to know because it relates to the income that will be received by the cocoa processing agro industry entrepreneurs in the "Kakao Unggul" Cooperation. To be more clear about the production costs incurred in the processing business of the "Kakao Unggul" Cooperation agro industry, Tanah Luas Sub District in North Aceh District can be explained in the following table:

The table above shows that with the total amount of pasta production and cocoa fat each of $125 \mathrm{~kg}$ and $104 \mathrm{~kg}$ and the use of raw materials as much as $300 \mathrm{~kg}$, then the value of processed cocoa production that can be produced in processing agroindustry in "Superior Cocoa" Cooperations in Tanah Luas Sub District, North Aceh District within one month of the 
production process which is Rp. $26,440,000$, as well as income earned by employers, which is Rp. 6,567,281, -.

Table 4 - Production costs and business revenues of processing Agro industry for "Kakao Unggul"

Cooperations in Tanah Luas Sub District, North Aceh District (one month production process), 2018

\begin{tabular}{lll}
\hline No. & Expenditures & Total \\
\hline A. & Variable Costs & \\
\hline & 1. Raw Material & Rp. 9.000 .000 \\
\hline & 2. Supporting Material & Rp. 91.000 \\
\hline & 3. Labor Cost & Rp. 8.060 .000 \\
\hline 4. General Cost (Electricity) & Rp. 850.000 \\
\hline & Invesment Cost & \\
\hline & - Depreciation of tools & Rp. 371.718,75 \\
\hline & Total Production Costs & Rp. 19.872 .719 \\
\hline & Production Value & Rp. 26.440.000 \\
\hline & Income & Rp. 6.567.281 \\
\hline
\end{tabular}

Source: Primer Data (Processed 2018).

Table 5 - Financial Feasibility of Cocoa Processing

\begin{tabular}{lll}
\hline No & Investment Criteria & Result \\
\hline 1. & NPV & 141.364 .032 \\
2. & Net B/C & 1,64 \\
3. & IRR & $35,69 \%$ \\
4. & BEP & 4 years 2 months 17 days \\
\hline
\end{tabular}

Source: Primer Data (Processed, 2018).

Net Present Value (NPV) calculation is an assessment conducted to compare Present Value (present value) of net cash and investment present value, the evaluation criteria for decision making is feasible to invest if the Net Present Value calculation results obtained are greater than 0 . Based on the results of the financial analysis above, it can be seen that the Cocoa processing agro industry in Tanah Luas Sub district produces a Net Present Value greater than zero, which is Rp 141,364,032. This shows that the Cocoa processing agro industry in Tanah Luas Sub district by the "Kakao Unggul" Cooperation will be able to provide net benefits at the present time of IDR 141,364,032 during the investment period of 5 years. Thus, based on the Net Present Value (NPV) assessment criteria, it can be concluded that this business is feasible for development.

The Calculation of Net Benefit Cost of Ratio, the purpose of calculating this criterion is to describe the effect of the addition of costs to the additional received. From the calculation results, the value of the Net benefit cost of ratio obtained by the Cocoa processing business is 1.64. This means that if the industry makes an investment of 1.00, it will get 1.64 times the net benefit or profit. The results of the analysis show that the value of the Net benefit cost of ratio obtained by this agro-industry is greater than 1 , so it can be concluded that the Superior Cocoa Cooperation Agro-Industry is feasible to be developed.

Internal Rate of Return is an assessment carried out with 2 interest rates to obtain a Present Value from a positive net cash flow and a Present Value from a negative net cash flow, an assessment indicator that is if the value of the Internal Rate of Return is greater than the prevailing interest rate in financial institutions, the business is feasible to implement and develop. From the results of calculations that have been done that the value of the Internal Rate of Return obtained is as much as $35.69 \%$ where this value is greater than the level of discount factor that is set at 12 percent. Based on the results of this calculation, it can be concluded that the cocoa processing agro industry at the "Kakao Unggul" Cooperation is able to repay loans with interest charged by banks to reach a high interest rate of $35 \%$. Thus, based on the Internal Rate of Return (IRR) assessment criteria, the Cocoa processing agro industry in the "Kakao Unggul" Cooperation is feasible.

Based on the analysis conducted by Break Event Point (BEP), Cocoa processing agro industry in Tanah Luas Sub district, North Aceh District occurred at 4 years 2 months 17 
days. This means that the Cocoa Agro industry business in Tanah Luas Sub district is feasible to be developed, because of the time period to return investment faster than the economic age of the cocoa processing agro-industry business.

\section{CONCLUSION}

Based on the analysis carried out on the prospects and development of the "Kakao Unggul" Cooperation agro industry in Tanah Luas Sub district, it can be concluded that the "Kakao Unggul" Cooperation Agro industry has a prospect to be developed, this is indicated by a review of the availability of the main raw materials in the Cocoa Cooperation Agro industry Superior in Tanah Luas Sub District can be obtained from Cooperation members and the surrounding community is available quite well. In terms of marketing aspects, cocoa processed products are very likely to be developed; this can be seen from the increase in the number of requests which continues to increase while the capacity and production capacity is still limited. The results of the analysis of the financial aspects of the cocoa processing agro industry business in North Aceh District are feasible to develop in terms of the Net Present Value of $141,364,032$, the Net benefit cost of ratio obtained at 1.64 , Internal rate of return (IRR) $35.69 \%$ and point return home (break even) occurs 4 years 2 months 17 days.

\section{REFERENCES}

1. Aisyah, S., Ma'arif, S., \& Arkerman, Y. (2014). Imitasi Proses Pemanfaatan Limbah Kakao Pendukung Strategi Inovasi Pengembangan Produk Hilir Agroindustri Kakao. Jurnal Teknik Industri Universitas Trisakti, 4(3). Retrieved from http://trijurnal.lemlit.trisakti.ac.id/index.php/tekin/article/view/78.

2. Dumairy. (1986). Matematika Terapan Untuk Bisnis dan Ekonomi. BPFE.

3. Praza, R. (2017). Identifikasi Saluran Pemasaran Kopi Arabika Gayo Pada CV. Gayo Mandiri Coffee Kabupaten Bener Meriah. Agrifo: Jurnal Agribisnis Universitas Malikussaleh, 2(1), 50-56.

4. Sutanto, R. (2002). Penerapan Pertanian Organik: Pemasyarakatan dan Pengembangannya. Kanisius.

5. Yacob, I. (2007). Studi Kelayakan Bisnis ( Edisi Revisi). Rineka. Cipta, Jakarta. 